\title{
TQM: the paradox of empowerment and conformance in the service sector
}

\author{
I.B. Hipkin \\ School of Management Studies. University of Cape Town. Rondebosch. 7700 South Nirica \\ ianh(a)infosys.uct.ac.za \\ August 1999
}

\begin{abstract}
TQM is an appealing intervention directed at establishing improved customer service. cultural transfiormation. empowerment and continuous improvement. involving everyone in the organisation in an integraled effort lowards enhanced performance at every level. Its appeal lies in its ability to encompass a quality programme. leading to excellence through participation. The diversity of activities done under the name of TQM is so wide that several atuthors have questioned whether it has an identifiable conceptual core. This presents an opportunity to managers to introduce a programme which they call 'TQM', with its attendant eminence, in order to implement changes. $A$ paradox arises when cmployees are encouraged to bring forward their own solutions (empowerment), yet they are constrained by company policies. procedures, or management edicts (conformance). This study describes the implementation of TQM in a South Alricin insurance company that wished to improve quality through empowerment. A questionnaire was administered to all members of a department involved with the TQM exercise. Wide differences in perceptions between managers. supervisors and ollicers ivere discovered. The diversity of opinions is discussed as a paradox between empowerment esperused hy management and the emphasis on conformance experienced by officers.
\end{abstract}

\section{Introduction}

TQM is characterised by paradox: while supporting the empowerment of individuals and the autonomy of groups through transcending traditional job demarcations, TQM emphasises the articulation of work processes through standards and procedures (Tuckman, 1994). TQM is critical of uncompromising bureaucracy, yet relies on the construction of rigidly defined roles through its establishment of procedures. Despite recent suggestions that TQM is no longer a vibrant management intervention (Fisher, 1994) and that TQM was essentially a 1980 s phenomenon (Hodgetts, Luthans \& Lee, 1994), the interest in and controversy surrounding TQM have scarcely abated. Notwithstanding the extensive debate over the longevity of the quality phenomenon, the reality is that managers claim that quality programmes have a strategic role in most large organisations (Almaraz. 1994).

While initially growing out of the concerns for quality assurance, where fitness for use and meeting customer requirements were narrowly associated with component manufacture. TQM has now become more explicitly a strategic weapon through managerial attempts at cultural transformation (Tuckman. 1994). In the management literature TQM has come to mean many things: it is often treated synonymously with culture change and excellence (Cronin, 1992), and is generally acknowledged as a major determinant of strategic direction and organisational change.

The purpose of this study is to consider TQM's effectiveness as a mechanism for empowerment, and to contrast this with conflicting views of TQM as a rigidly defined bureaucratic process which demands conformance to standards and procedures. The research uses the case study approach, limiting this exploratory study to an analysis of one organisation. In so doing we are guided by Mersha:
'Statistical validity often may not be the focus of corporate research. Rather. it may be the better understanding, description and prediction of events that have an impact on decision making' (1997: 165).

This article discusses some underlying principles and implementation patterns of TQM, with particular reference to the literature relating to TQM as an empowerment tool. These theoretical issues will be considered in the light of the experiences of a South African service organisation. Perceptions arising from TQM implementation are presented. followed by preliminary findings. implications for managers and limitations of the research.

\section{Some underlying principles of TQM}

With its roots in the development of mass production in the USA (Schroeder \& Robinson, 1991), TQM emerged as a selfcritique of western management styles in the sphere of quality, as well as a western attempt to cuunter Japanese industrial success (Boje \& Winsor. 1993: Tuckman. 1994). Factors contributing to the rising popularity of TQM have included the imposition of stringent quality requirements by customers, a drive to reduce costs and improve performance. increased contact with Japanese companies. and published case studies which focus on how companies have set about developing TQM programmes and measuring the benefits derived from TQM (Dale. Lascelles \& Plunkett. 1990). Current approaches to TQM require the generation of objective data to improve systematically work processes and products. focusing on employee involveinent. empowerment. customer requirements and supplier performance (Govender. 1998: Hackman \& Wageman. 1994; Lam. 1994; Seaker \& Waller. 1994; Sitkin, Sutcliffe \& Schroeder. 1994).

The work of the quality gurus. such as Crosby (1979). Deming (1982). Feigenbaum (1983). Imai (1986) and Juran (1991), must be acknowledged in any discussion of TQM. 
Subtle differences exist in some of their approaches. For example, Juran takes a mechanistic engineering approach to tackling quality control with primary responsibility on quality professionals (the role of the workforce being minimal), while Deming and Feigenbaum ignore the cost of quality, devoting more attention to workforce involvement, the importance of cross-functionality and emphasising the need for organisational culture change (Dale et al., 1990). Essentially, their work may be summarised as doing things right first time, striving for continuous improvement, and treating the organisation as a total system (Sitkin et al., 1994).

There is no established, valid methodology or industry standard for introducing TQM (Black \& Porter, 1996; Flynn, Sakakibara \& Schroeder, 1994; Smith, Tranfield, Foster \& Whittle, 1994), although its proponents maintain it contains three core elements (Luthans, Rubach \& Marsnik, 1995; Rust Keiningham, Clemens \& Zahorik, 1999):

- a focus on the customer through gathering and processing of data;

- emphasis on participation, empowerment and teamwork; and

- continuous improvement.

The common approach to introducing TQM is to adopt the teachings of one of the management gurus and/or use the services of a major consultancy. The initial phase is generally well received with people keen to become involved in making improvements in their own areas. After a while the organisation reaches a plateau where activity drops off. Senior managers pay less attention to TQM activities, allowing cynicism to creep in with employees increasingly describing it as 'last year's flavour of the month' (Cook \& Blaxter, 1991).

Management theory now portrays some revisionism in questioning the claims of TQM (Eadie, 1999), with few authors denying that the road to TQM is littered with failures (Grant, Shani \& Krishnan, 1994). Although most large organisations have initiated quality programmes, many of these have never fulfilled their initial promises (Steininger, 1994). A variety of surveys have reported few significant improvements and meaningful impact on organisational activities (The Economist, 1992; Fisher, 1994). Drucker, Hammer, Nadler \& Champy (1993) speak of 'widespread disenchantment with the once beloved TQM'. In many cases, the reasons for failure are remarkably similar to those of quality circles: TQM is organised in parallel with existing structures, thereby being perceived as an organisational 'extra', which is too ambitious for the organisation to accommodate, and with employee input promised but power not moving from managers (Cronin, 1992). The problem of empowerment has been characterised by a chasm between front-line workers' involvement and their accountability, caused by management's fear of losing control (Hackman \& Wageman, 1994).

Implementation failures are frequently attributed to managerial attitudes and organisational culture (Dale et al., 1990; Forker, Mendez \& Hershauer, 1997; Kasul \& Motwani, 1997; Tamimi, 1995). In the popular management literature TQM is represented as presenting a radical challenge to traditional management thinking and practice (Grant et cl., 1994). Managers are blamed for seeking quick fix solutions, and underestimating the long and arduous journey demanded by TQM, with managers' propensity to take short cuts undermining im- plementation. Only recently have design features of TQM programmes themselves come under scrutiny, with emphasis being placed on planning the implementation and the management of change (Almaraz, 1994).

Most literature on the evaluation of TQM programmes is limited by the fact that it is anecdotal and survey based, listing benefits and difficulties concerning implementation (Barker, 1994; Cronin, 1992; Hackman \& Wageman, 1994). Seldom is there any indication of whether perspectives of different stakeholders in an organisation may be significantly different, or how they gained their perspective on TQM in the first place (Barker, 1994).

Concluding that TQM is a conspiracy to de-humanise the worker is a simplistic reaction to the TQM empowerment paradox. Several authors have tried to unbundle and examine critically the TQM package (Barker, 1994; Boje \& Winsor, 1993; Sitkin et al., 1994; Spencer, 1994; Tuckman, 1994): their approaches share the premise that TQM is essentially a paradoxical phenomenon and we have to disentangle the different assumptions underlying TQM.

The stated goal of TQM is to improve quality through successful conversion to a quality culture (Abraham. Crawford \& Fisher, 1999), but frequently, the real objective is to increase productivity and efficiency within the organisation. This is especially prevalent in the writings of the gurus (such as Crosby) but even now that the TQM literature has matured, there is still an emphasis on achieving cost savings, eliminating personnel, and bolstering profits (Boje \& Winsor, 1993). Even though TQM may provide greater freedom of action than mechanistic management practices, it actually may reduce freedom of choice by submitting employees to "awareness training' designed to create a common frame of reference and to skills training aimed at establishing preferred ways of solving problems and working with teams (Chen. 1997). Especially with the advent of the 'excellence' approach and its incorporation into TQM, management has become directly and intentionally involved in determining what employees believe, think, and value (Boje \& Winsor, 1993). The research described in this article asks about the extent to which empowerment takes place, and assesses how much of the TQM implementation merely represents management imposition by means of an ostensibly external intervention process.

\section{Case outline}

The practical application of some of the theoretical points discussed above will be considered in the light of the experiences of a case organisation: the claims department of a large South African insurance company, dealing with personal, household, motor and commercial insurance. The company had introduced 'TQM as a strategic response' (Mann \& Kehoe, 1995) to an alarming increase in the number of complaints from brokers and policyholders (both of whom were to be regarded as customers), adverse comments and declining business as a result of perceived poor performance in the settling of claims. The claims department consisted of a manager, three assistant managers, six supervisors, and 37 operations and clerical staff with various titles and levels of responsibility which will be collectively referred to as claims officers. 
Prior to the TQM exercise, claims were received either from brokers or directly from policyholders. All claims were initially scrutinised by a supervisor, who referred 'large' claims to an assistant manager (there was little consistency as to what constituted a large claim), although assistant managers were more concerned with inflated or fraudulent claims. The supervisor would instruct an officer to investigate a claim and contact an assessor or another insurance company where appropriate. Once the assessor's report was received, the supervisor would approve, modify or disallow the claim. The officer would report this to the client and arrange for payment.

Increasingly negative feedback from customers led managers to believe that the claims department was not customer focused, and that contradictory policies and procedures were detrimental to consistency and high professional standards. Comments from customers revealed the perception that the aim of the insurance company was solely to maximise its wealth, and that reducing claims or not paying these at all were invariably achieved by resorting to the 'small print' in policy documents. Declining business and a staff demoralised by customer complaints forced management to address the lack of customer scrvice orientation: TQM was the proposed solution.

\section{TQM implementation in the case organisation}

Management launched the TQM exercise with a policy statement for the whole company which included the words

'TQM will be the vehicle for ensuring continuous improvement, by empowering and involving everyone in the organisation. Through the commitment of staff we shall provide customers with nothing less than excellent service'.

Management had specifically stated prior to commencing with TQM that empowerment of their employees was to be a major aspect of TQM implementation.

The goals were set out as follows:

- standardise the procedures, styles and approaches to customer service interactions throughout the department;

- manage customer satisfaction levels (increase the number of delighted customers; minimise the number of dissatisfied customers); and

- empower staff to decide on the ways in which goals are to be achieved.

All departmental members attended a two-day TQM training course. A task team of one manager, three supervisors and three officers was established to initiate the TQM process. The intention was for the task team to identify, and prioritise problem areas, analyse these, and suggest improvements by fully involving all those associated with the selected activity. However, management had already identified a number of areas which were to be studied (there was no supervisor or officer involvement in choosing these areas):

- multi-tasking, whereby one officer could be dealing with up to 50 claims at one time, was to be investigated, as a reason for great inefficiency;

- the number of referrals from officer to supervisor (and on occasion to assistant managers) was the main reason for lengthy delays in processing claims;

- claims were expedited once queries by brokers were re- ceived; otherwise it was not uncommon for claims to remain pending for months. usually while waiting for supervisor or manager scrutiny:

- empowering officers to deal with a claim in totality below a certain monetary amount was seen as a way to reduce delays: officers were to be permitted to investigate where they deemed it appropriate, and to accept assessors ${ }^{\circ}$ valuations if these seemed reasonable:

- the complexity of and level at which claims had to be referred to supervisors were to be determined: and

- details of a computerised claims tracking system. selected by management, were to he finalised prior to implementation.

Involvement by all employees and the need for changes in organisational culture were soon seen to be elusive. Despite suggestions and strong justification from the officers that claims be processed in order of arrival. managers continued to demand flexibility in the schedule. This was interpreted by officers as the way in which managers pacified brokers, only to antagonise others whose claims were further delayed. When challenged on their decision, management maintained that their managerial prerogative enabled them, in exceptional circumstances., to determine priorities and that such decisions were beyond the scope of TQM

The real agenda behind the adoption of TQM emerged with managers' frequent questioning about the impact of proposed changes on the workforce. Employees were well aware of reports in the press and elsewhere that the insurance industry was overstaffed. When a proposal by the task team was made for clerks to undertake minor checking tasks. managers immediately seized on the suggestion and sought redeployment of some officers. Officers questioned whether management truly sought the culture change which would lead to greater efficiency, or whether in truth they wanted a reduction in the workforce. Managers insisted that it was only natural to derive maximum benefit for the company from any changes that occurred, and that it was unfortunate if retrenchments ensued.'

During the TQM investigation phase. it was discovered that subsections dealt with claims in different ways. Numerous forms had been drawn up and the bases for referrals to higher authority were not consistent. Management was astounded at the variety of procedures, and immediately instituted a standardised way of handling all claims. This illustrated the transparency of involving all levels of staff: procedures were set by management who demanded acceptance without question. despite repeated protestations by officers that these could not be achieved under present operating circumstances. lmplementing TQM became a process of oheying the prescriptive directives of management.

Changes yielded improvements in procedures, which may well never have resulted had there been no TQM initiative in the first place. However the culture of continuous improvement did not exude ubiquitousty, and customer complaints continued to be dealt with in an ad hoc way. There was scepticism among officers as to how much empowerment had taken place. The task team had been invited to contribute to the problem definition stages. but procedural changes had been drawn up by managers and supervisors, with little subsequent recourse to the operations staff. 
No criteria were set against which success or failure of TQM could be measured, so benefits of the change programme were subjectively assessed, and selectively publicised by management as illustrations of TQM successes.

\section{Perceptions of TQM}

Some twelve months after the first phase of TQM implementation, all employees in the claims department were requested to complete a questionnaire seeking their views on a wide range of issues related to TQM. Employees were asked to rate their opinions of each of the statements in Table $1^{2}$ on a 5 point Likert scale. The right-hand column in Table 1 gives a measure of the range of opinion: usually the greatest difference was between the scores of the managers and the officers. Altogether 12 follow-up interviews (with two managers, three supervisors and seven officers) were held to obtain richer information and to seek deeper insight and clarification on points arising from analysis of the questionnaire, particularly those related to empowerment.

A wide divergence of opinion is evident for certain factors in Table 1. Scores relating to vision show that managers believed that they had thoroughly prepared for TQM. Apart from questioning the plan detailing steps for change and how changes would impact on jobs, supervisors were in general agreement that the company vision for TQM was adequate. The difference in perceptions lies with the officers who mostly disagreed on the clarity of vision when TQM was launched. During subsequent interviews, officers were adamant that there had been very little discussion prior to TQM, and that the process was imposed on them by management. This was reiterated when empowerment was discussed in the interviews: if there was no involvement and consultation at the outset, how could managers expect that empowerment would materialise at a later stage?

Perceptions relating to management practice also revealed differences between managers and officers: the latter did not accept that senior management was sharing and championing a quality vision, nor that management support was available to those grappling with new thinking.

Systems support suffered from officers' beliefs that management was not open to consultation on systems issues. One officer commented: 'in demonstrating that they were not always readily available to discuss TQM, managers seemed to be sending the message that TQM was one way for achieving change, but at the end of the day, they will decide what systems will be used. This is not empowerment'. The lack of a clear timetable for the various TQM phases illustrates the difficulty in planning implementation for a process which is not easily defined. Officers were firm in their view that they did not receive adequate training, or even guidance, for carrying out new tasks which were introduced as a result of the TQM process.

There were numerous issues which showed divergence under the reward, motivation and empowerment heading. Officers believed that failure to 'go along' with TQM would be to their detriment. They remained cynical about TQM as they had seen that it did not lead to genuine empowerment in which they played a meaningful part in influencing procedures and policies. Officers decisively rejected managers' views that everyone was given the opportunity to participate in determining future policies: while a task team containing three officers had been established. it became apparent that the team was effectively powerless, and that managers selected which activities would be studied, and steered the team towards the solutions which managers sought. Frequently this was done by managers' creating policies or setting barriers on the spur of the moment.

Managers did not score items 4.17 ('I feel empowered') 4.18 ('I have additional authority') and 4.19 ('I am part of the decision-making process'), so the ranges of figures in Table refer only to the difference in perceptions between supervisors and officers. These reflect the officers highest scores of disagreement: they did not experience empowerment, they did not have additional authority and they did not feel part of the decision-making process.

Communication about TQM presented no strong disagreement. Of significance under the quality and behaviour heading were the officers' beliefs that cultural change had not occurred, and that improvements had not been (and indeed could not be) quantified. Officers indicated that cultural change could not result from a process which was driven and imposed by management: this explains the score (item 4.6) where officers strongly disagreed with managers in that "we are going through the motions of TQM'.

Managers clearly believed that TQM had empowered officers, and was bringing about organisational culture change. They also were convinced that TQM goals had been made clear, and that these had generally been achieved. The response from one official to this was "well they would say that. wouldn't they: it was their idea, and TQM had to be shown to be working'.

Officers' views were in many respects opposite to those of management: disagreement that empowerment had resulted. with only limited support for the idea that organisational culture had changed. Officers felt they had made a serious contribution to TQM, but there was a strong feeling that additional responsibility had shifted to them. considerably increasing their work load (hence their perception that productivity had improved). However, in the interviews, officers were adamant that there had been no increase in decisionmaking power which in any way affected their control over the situation for which they were now held responsible. Quality was indeed a force in TQM, but officers did not feel they were directly concerned with client requirements: rather, it was quality for internal efficiency's sake.

Supervisors' opinions lay between those of managers and officers, illustrating that supervisors are

'squeezed between the demands of (managers') strategies which they do not influence, and the ambitions of increasingly independent-minded employees' (Dopson

\& Stewart, 1993: 11).

During subsequent interviews, the paradox between empowerment and conformance to managerial edicts became apparent. Managers firmly believed that the TQM task team had been given the opportunity to take the initiative, and that. with few exceptions the team's suggestions were being investigated. if they had not already been implemented. Part of the empowerment process meant that officers were given responsibility for scheduling their work and for meeting targets (elapsed time for dealing with each claim). Managers did not 


\begin{tabular}{|c|c|c|c|c|c|}
\hline & & $\begin{array}{c}\text { Manlager } \\
N=4\end{array}$ & $\begin{array}{l}\text { Supervisot } \\
N=6\end{array}$ & $\begin{array}{l}\text { ()iticet } \\
N=33\end{array}$ & Range* \\
\hline 1 & Vision: the introduction of TQM was accompanied by & & & & \\
\hline 1.1 & A clear rationale for the emphasis on quality & 10 & 17 & 21 & 11 \\
\hline 1.2 & An explanation of the advantages of TQM to all einployees & 10 & 1.5 & 2.2 & 12 \\
\hline 1.3 & A discussion of specific ways in which structures, systems and people practices would change & 12 & 19 & 27 & 15 \\
\hline 1.4 & A description of new core values and/or beliefs needed to make the change successful & 12 & 17 & 24 & 12 \\
\hline 1.5 & A plan detailing the various steps for change & I $x$ & 26 & 31 & 13 \\
\hline 1.6 & A clear impact of how the change would impact upon my job & 1.8 & 2.8 & 3.4 & 15 \\
\hline 2 & Management practice & & & & \\
\hline 2.1 & Senior management created a belief that the old ways were unsatistactory & 15 & 17 & 16 & 112 \\
\hline 2.2 & From the beginning there was clear evidence of senior management sharing and championing a quality vision & 111 & 21 & 29 & 14 \\
\hline 2.3 & There was clear evidence of a particular person driving change & 10 & 15 & $1 . x$ & 118 \\
\hline 2.4 & Management time, patience and support were given to those who experienced difficulties in adjusting to new ways & 15 & 24 & 33 & 18 \\
\hline 3 & Systems support & & & & \\
\hline 3.1 & $\begin{array}{l}\text { Throughout the transition to the new quality culture, there were distinct people from whom I could get answers/action on } \\
\text { systems issues }\end{array}$ & 12 & 26 & $2 x$ & 16 \\
\hline 3.2 & Adequate financial resources were allocated to TQM & 15 & 18 & $\mathrm{Ix}$ & 113 \\
\hline 33 & Adequate human resources were allocated to TQM & 16 & 20 & 22 & 106 \\
\hline 3.4 & There was a clear timetable for the various phases of TQM & 15 & 26 & $3 i$ & $1 x$ \\
\hline 3.5 & I received appropriate training to enable me to understand TOM & 12 & 15 & 15 & $1) 3$ \\
\hline 4 & Notivation, rewards and empowerment: I support the quality culture because & 211 & 36 & 42 & 22 \\
\hline 4.1 & It provides satisfaction tor doing a job well & 16 & 22 & 33 & 17 \\
\hline 4.2 & If people did not go along with it they would be penalised & +11 & 33 & 16 & $-2+$ \\
\hline 43 & People get paid more & 311 & $3 x$ & 48 & $1 x$ \\
\hline 4.4 & My team meinbers expect me to act in ways that emphasise quality & 111 & 18 & 21 & 11 \\
\hline 4.5 & There is little chance of advancement unless one has embraced quality principles & 26 & 22 & 15 & -11 \\
\hline 4.6 & I play the game but inside I am still cynical about the whole thing & $+x$ & 27 & 211 & -28 \\
\hline 4.7 & Managers set examples by modelling appropriate behaviour & 12 & 22 & $2 \times$ & 16 \\
\hline 4.8 & If 'quality' were not continually emphasised from the top, things would just go back to the way they werc & 24 & 22 & 14 & -15 \\
\hline 4.9 & $\begin{array}{l}\text { I believe people have internalised quality so completely that the appropriate behaviours would occur no matter who wils } \\
\text { driving the shou }\end{array}$ & 32 & 35 & 3 & 111 \\
\hline 4.10 & People were given the full opportunity to participate in any changes & 15 & 26 & +2 & 27 \\
\hline 411 & Management was pleased to receive suggestions for improvement & I11 & 21 & 34 & $2+$ \\
\hline 4.12 & Prompt leedback was given on any suggestions made & $2 n$ & 34 & 42 & 12 \\
\hline 4.13 & Management was prepared to act on these suggestions & 22 & 35 & $4+$ & 22 \\
\hline 4.14 & I teel a sense of personal 'ounership' of the quality culture & 12 & 24 & 30 & $1 x$ \\
\hline 415 & People who model high quality standards are recognised in visible ways & $\operatorname{lx}$ & 26 & 32 & 14 \\
\hline+.16 & People who devate trom high quality standards are penalised in visible ways & 36 & 28 & 22 & $1, x$ \\
\hline+17 & Overall. I feel empowered as a result of the TQM exercise & $n$ & 25 & $+i$ & $\mid x$ \\
\hline+18 & I have additional authority to accompany the addutional tasks which I now perform & nis & 34 & $4+$ & 111 \\
\hline+19 & $\begin{array}{l}\text { I um part of the decision inaking process which greses ine the opponunity to make suggestions free from managine:nt } \\
\text { opinions }\end{array}$ & "ra & $2 x$ & 3 & $i i$ \\
\hline+20 & TOM has shifted the responsibility for organisational problems trom senior management to lower lei cls & 34 & 16 & 16 & 211 \\
\hline 5 & Communication about TQM & & & & \\
\hline 5.1 & There were regular "quality" messages on noticeboards and in news ttems in the company newspaper & $1 x$ & 211 & 21 & $1 ; 3$ \\
\hline 52 & The messages and new items were effective & $2:$ & $2 x$ & 34 & 111 \\
\hline 53 & Meetings were held to communicate changes & $1 x$ & 24 & 29 & 11 \\
\hline 6 & Quality and behaviour & & & & \\
\hline 6.1 & Cultural chisnge has profoundiy affected organisational values regarding customers & $1 x$ & 25 & $3:$ & 15 \\
\hline 62 & Cultural change has aftected organisational values regarding compettion & 21 & 311 & 36 & $i=$ \\
\hline 63 & We now have an unproved service & $x$ & 22 & $2 "$ & $1 i$ \\
\hline 64 & Productwity is (subjectively) higher & $1:$ & $1 x$ & $1 x$ & 1,3 \\
\hline 6.5 & Improvements have been quantutied & $=1$ & $\therefore 2$ & 34 & $1 x$ \\
\hline
\end{tabular}

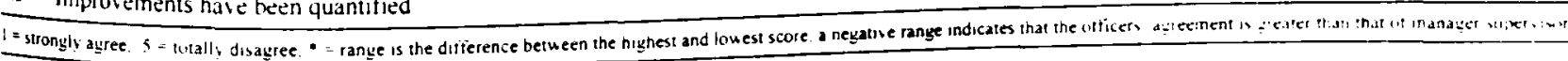


share the view that no commensurate power accompanied the increased responsibility: the very process of empowerment meant that power was devolved. Yet, officers noted that managers had decided what the duration target was for dealing with claims.

During the interviews every official stated that the agenda hidden within TQM was to improve efficiency and to reduce the workforce. The main reason for their saying that goals had not been made sufficiently clear was that management had announced one set of objectives, but evidence suggested that the real aims lay elsewhere. Officers acknowledged that some of their suggestions had been accepted, particularly if little additional expenditure was to be incurred. However, they pointed to instances where additional expenditure was required (and in their view justified), but none of these suggestions had been accepted. There was an overwhelming feeling that TQM was used to enforce adherence to what management wanted and that greater conformance to managerial decisions inevitably detracted from the empowerment process. Managers did not seem to appreciate the depth of officers' opinion in this regard.

\section{Preliminary conclusions and implications for man- agers}

In this case organisation management assumed that the central features of TQM were quality, empowerment and cultural transformation leading to operational excellence. Yet, conflicting views of managers and officers in their assessment of the role of these features suggest that the 'intrinsic' characteristics were far from clear. It is thus evident that TQM may occasion organisational change, not as the linear view to change would hold, because of its intrinsic characteristics (Pettigrew, 1987), but rather because it becomes a social object whose meanings are defined by the context wherein it is used (Markus \& Robey, 1988). Our study has shown that the meanings and values associated with quality processes and outcomes varied by hierarchical level as reflected by radically differing contexts. Consequently, both researchers and practitioners have to look for clues concerning the meaning of quality from multiple points of view.

While consultants claim that TQM's attributes can be used in the effective management of change, the problem in practice is that companies, rather than questioning what the programme should be achieving. seem to follow TQM on the basis that if they do implement TQM, they are more likely to succeed (Badri, Davis \& Davis, 1995; Fisher, 1994). This is borne out by managers' responses, broadly pronouncing successful implementation, through instances of quicker processing of claims and increased productivity. The differing views of officers show that initial enthusiasm faded because of illdefined aims and limited measurable success. There were clearly divergent views as to whether TQM had been successful.

TQM is often depicted as representing a challenge to traditional managerial thinking (Grant et al., 1994; Sarazen, 1991), but officers saw little evidence of this. Management viewed officers as reluctant to take on the additional responsibilities offered by empowerment; officers concluded that managers were loath to relinquish power. Even within the ranks of the officers, there was resistance to a reduction in horizontal job demarcation, although this was not perceived as intractable as the inability to break down the barriers of vertical demarcation. The change in the nature of officers' duties and responsibilities was seen by the officers as aggravating bureaucratic constructs. Herein lay the fundamental paradox: management's perception of greater empowerment and officers' feelings of constraint. Supervisors resisted some of the empowerment advances as these represented a threat to their authority. Drucker (1988: 47) has expressed this as a transformation of their role to one of 'serving as relays, human boosters for the faint, unfocused signals that pass for communication'.

Any theory that offers a means of intervening in a social system requires some view about how current beliefs and perceptions are likely to be affected by particular interventions and by the probable consequences of such change (Whitley, 1989). TQM was presented by the management as an intervention mechanism in the organisational social system. with the intention that attitudes and behaviours would be subsumed in a total quality culture. However, managers acknowledged that their initial objectives had not fully materialised because of divergent interpretations and expectations: this emphasises our point that proponents cannot treat TQM as a discrete entity change programme with an existence and identity independent of the organisation in which it is implemented (Spencer, 1994).

The rules and techniques of TQM can also be seen as procedures for transforming micro-political problems (such as the time taken to process claims because of constant reterral to higher authority) into technical issues (using a computerised tracking process) which more detailed knowledge and better management techniques promise to solve (Marsden. 1993; Mintzberg. 1989). Built into the programmes are mechanisms for improved operating methods which appear as conformance or norms of appropriate behaviour (Cooper \& Burrell, 1988). These in turn help management reduce uncertainty (who is sitting on a claim, and for how much longer?) and make organisational reality more manageable (easier to monitor a claim's progress).

While only one company was studied in this analysis. the implications for managers are significant. Goals and perceptions were frequently at variance. creating the impression amongst officers that TQM is set another way for management to bring about their desired changes. but this time with ostensible support from the entire workforce. Clear objectives whose achievements have face validity are the essential tirst step. Cultural transformation does not take place by setting up groups to study problem areas. and empowerment must be seen to be accompanied by commensurate changes in power bases, without which TQM will become a technique for ensuring conformance. and progress no turther. The challenge for managers and officers is to combine their disparate views in order to attain the goals set out for the TQM exercise. This would require empowerment to be defined so that its operationalisation can be clearly identitied. There was remarkably little discussion between managers and officers regarding the views of the latter that conformance to managerial edict nullified attempts at empowerment. 


\section{Limitations and areas for further research}

The study commenced one year after the first phase (investigation, initial recommendations and implementation) of TQM had been completed. Insufficient time had elapsed for extensive measures to be instituted to assess quantifiable benefits from the intervention, so improvements could only be subjectively appraised: reliance was therefore made on subjective comments by interviewees and from their scores of the items in Table 1. Although not all suggestions had been implemented, managers were satisfied that the most important issues had been addressed. The study covered only one part of one organisation, and thus suffers from all case study research: the validity of broader generalisation, both to other departments within the company, and to other organisations. However, the insight gained from this limited investigation provides useful groundwork for 'analytical generalisation' (Yin, 1989) and further theory building research, from a larger sample of organisations.

The investigation did not attempt to study a key aspect in the management of services: the customer. Further research could usefully address how TQM within the insurance company has influenced customer service from the customer's perspective.

\section{Conclusion}

This article has considered TQM implementation in one organisation. TQM was not deemed an unqualified success, yet benefits were forthcoming. The articulation of quality enhancement through work processes and procedures reduced the commitment to total acceptance of TQM and detracted from a feeling of empowerment by officers. A noteworthy feature was the difference in perceptions between managers and officers in their broad understanding of TQM, how effectively it was implemented and the empowerment which was intended. It is clear that TQM should not be treated as an externally devised change programme which can be applied without consideration of the organisation in which it is implemented, but should be introduced as a social intervention whose meanings will be partially defined by the context wherein it is used.

The case organisation did not fully embrace TQM, so its implementation was largely a wasted opportunity: TQM failed to act as a binding mechanism (De Cock \& Hipkin, 1997) for continuous commitment to quality, largely because of officers' suspicions of management's real agenda behind the intervention; it was also not able to provide the empowerment which had been so much part of the initial 'selling' process, predominantly because officers perceived it as a way of management enforced conformance. The challenge to managers must be to reflect on the philosophical and psychological assumptions in organisations which seek to transform themselves into those which continually manage quality (Steininger, 1994).

\section{Notes}

1. At the time of the research there had been no retrenchments (although these had not been ruled out); several vacated posts had not been filled.

2. The factors are adapted from the study by Abraham et al. (1999).

\section{References}

Abraham. M.. Crawford. J. \& Fisher. J. 1999. Key factors predicting effectiveness of cultural change and improved productivity in implementing TQM. International Iournal of Quality and Reliability Management. 16(2): 112-132.

Almaraz, J. 1994. Quality management and the process of change. Journal of Organizational ( hange Management. 7(2): 6-14.

Badri, M.A.. Davis. Donald \& Davis. Domma. 1995. A study of measuring the critical factors of quality management. International Journal of Quality and Reliability Management. 12(2): 3653.

Barker, R. 1994. Relative utility of culture and climate analysis to an organizational change agent: an analysis of general dynamics. Electronics Division. The Internotional Journal of Organizational Analysis. 2(1): 68-87.

Boje. D.M. \& Winsor. R.D. 1993. The resurrection of taylorism: total quality management's hidden agenda. Journal of Organizational Change Management. 6(4): 57-70.

Chen, W-11. 1997. The human side of TQM in Taiwan: leadership and human resource management. International Journal of Quality and Reliability Management. 14(1): 24-45.

Cook. D. \& Blaxter. T. 1991. Maintaining Inomentum. Total Quality Management. June: 149-151

Cooper. R. \& Burrell. G. 1988. Modernism. postmodernism and organizational analysis: an introduction. Organization Studies. $9(1)$ : 91-112.

Cronin. E. 1992. Implementing service cuality programmes in UK retail financial services: the role of human resource management. Unpublished PhD dissertation. Manchester Business School. University of Manchester.

Crosby. P.B. 1979. Quality is free. New York: McGraw Hill.

Dale. B.G.. Lascelles. D.M. \& Plunkett. J.J. 1990. The process of total quality management. In Dale. B.G. \& Plunkett. J.J. eds. Managing quality. pp. 3-17. Philip Allan.

De Cock C. \& Hipkin I.B. 1997. TQM and BPR: beyond the beyond myth. Journal of Management Situdies. 34(5): 659-675.

Deming. W.E. 1982. Qualit! productivity and competitive position. Boston: MIT Press.

Dopson. S. \& Stewart. R. 1993. Information technology. organizational restructuring and the future of middle management. New Technologv. Work and Emplowme'n. 8(1): 10-20.

Drucker, P.F. 1988. The coming of the new organisation. Harvard Business Review, January-February: 45-53

Drucker, PF., Hammer. M.. Nadler. D. \& Champy. J. 1993. Fads. fixes and fictions. Management Today. June: 40-42.

Eadie. A. 1999. When empowerment fails. Financial Times. 29 July Economist. 1992. 'The cracks in quality'. 18 April.

Feigenbaum. A.V. 1983. Total quality control. New York: McGiraw Hill.

Fisher. L. 1994. Total quality: hit or myth'. Accountancy: $50-51$.

Forker, L.B.. Mendez. D. \& Hershauer. J.C. 1997. TQM in the supply chain: what is its impact on performance'? International Journal of Production Research. 35(6): 1681-1701.

Flynn, B.B., Sakakibara. S. \& Schroeder. R.(i. 1995. Relationship between JIT and TQM: practices and performance. Academy of Management Journal. 38(5): 1325-1360).

Govender. K.K. 1998. Managing service quality by managing customer service. South African .Journal of Business Alanagement. 29(3): 89-99.

Grant. R.M.. Shani. R. \& Krishnan. R. 1994. TQM's challenge to management theory and practice. Slom Management Review: $25-$ 35.

Hackman. J.R. \& Wageman. R. 1994. Total quality management: empirical, conceptual and practical issucs. Administrative Sicience Quarterly, 40: 309-342.

Hodgetts, R.M. Luthans. 1: \& Lee. S.M. 1994. New paradigm or- 
ganizations: from total quality to learning to world class. Organizational Dynamics. 23 (Winter): 5-19.

Imai, M. 1986. Kaizen. New York: Random House.

Juran. J.M. 1991. Strategies for world-class quality, Quality

Progress. March: 81-85.

Kasul. R.A. \& Motwani, J.G. 1995. TQM in manufacturing, International Journal of Quality and Reliability Management, 12(3): 5776.

Lam. S.S.K. 1995. Quality management and job satisfaction, International Journal of Quality and Reliability Management, 12(4): 72-78.

Luthans. F., Rubach. M.J. \& Marsnik, P. 1995. Going beyond total quality: the characteristics, techniques and measures of learning organizations. International Journal of Organizational Analysis, 3(1), 24-44.

Mann. R. \& Kehoe, D. 1995. Factors affecting the implementation and success of TQM. International Journal of Quality and Reliability Management. 12(1): 11-23.

Markus. M.L. \& Robey, D. 1988. Information technology and organizational change: causal structure in theory and research. Management Science, 34(5): 583-598.

Marsden, R. 1993. The politics of organizational analysis, Organization Studies, 14(1): 93-124.

Mersha. T. 1997. TQM implementation in LDCs: driving and restraining forces, International Journal of Operations and Production Management. 14(2): 164-183.

Mintzberg. H. 1989. Mintzberg on management: inside our strange world of organizations. New York: Free Press.

Pettigrew. A. 1987. Context and action in the transformation of the firm. Journal of Management Studies, 24: 649-671.

Rust. R.T., Keiningham, T., Clemens, S. \& Zahorik, A. 1999. Return on quality in Chase Manhattan Bank, Interfaces, 9(2)l: 62-72.

Sarazen, J.S. 1991. Continuous improvement and innovation, Journal for Quality and Participation, September: 34-39.
Schroeder, D.M.\& Rohinson, A.(j. 199)1. America's most successfil export to Japan: continuous improvement programs. S/oan Management Review, Spring: 67-79.

Seaker, R. \& Waller. M.A. 1996. Brainstorming: the common thread in TQM, empowerment, re-engineering and continuous improvement, International Journal of Quality and Reliability Manage. ment, 13(1): 24-31.

Sitkin, S.B., Sutcliffe. K.M. \& Schroeder. R.(i. 1994. Distinguishing control from learning in total quality management: a contingency perspective. Academy of Management Review. 19(3): 537-564

Smith, S.. Tranfield. D. Foster. M \& Whittle. S. 1994. Strategies for managing the TQ agenda. International .fournal of Operations and Production Management. 4(1): 75-88.

Spencer, B.A. 1994. Models of organization and total quality management: a comparison and critical evaluation, Academy of Management Review. 19(3): 446-471.

Steininger, D.J. 1994. Why quality initiatives are failing: the need to address the foundation of human motivation. Human Resource Management. 33(4): 601-616.

Tamimi. N. 1995. An empirical investigation of critical TQM factors using exploratory factor analysis. International Journal of Production Research. 33(11): 3041-3051

Tuckman, A. 1994. The yellow brick road: total quality management and the restructuring of organizational culture. Organization Studies, 15(5): 727-751.

Whitley, R. 1989. Knowledge and practice in the management and policy sciences. Working Paper No. 174. Manchester Business School, University of Manchester.

Yin, R.K. 1989. Case study research: design and methods. Newbury Park: Sage Publications. 